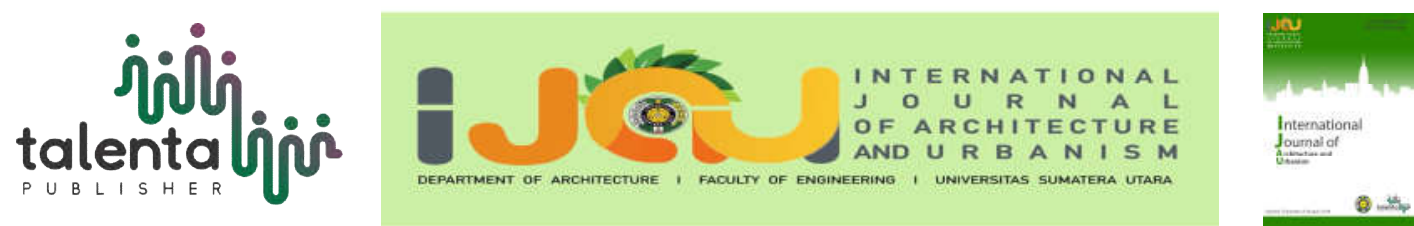

\title{
North Sumatera Convention Center
}

\author{
Andalucia $^{1 *}$, Marini $^{1}$ \\ ${ }^{1}$ Department of Architecture, Universitas Sumatera Utara, Medan, Indonesia
}

\begin{abstract}
Sumatera Utara has enhancement of population growth around $2.33 \%$ per year and economic growth around $14.7 \%$ per year. By all means, this data effect on trade sector, industry sector, entertainment sector, and education sector. From the data above can be obtained that Medan needs supporting facilities to organizing even such as conference, exhibition, a party even, or concert which nationally or internationally. There are a few even for entertainment and art in Medan seen from rarely held music or art performance nationally or internationally. Moreover, there is a very few venue to hold it. North Sumatra Convention Center is built at Jl. H. Adam Malik. This location is chosen because it is by the District of West Medan, which is destined for commercial building supporting the economy. The theme of the design is Contemporary Architecture. This theme is the result of the author's thought to make this building also become Landmark Medan. With the design of the new Convention Center in Medan itself aims to create a place for conference and other activities. The international convention center design is also expected to improve the quality and quantity of similar development for community place and improve the economy of Medan with regions and other countries. The design of North Sumatra Convention Center is expected to be able to support the big activities as mentioned above.
\end{abstract}

Keyword: convention, wide-span, contemporary, space-frame

\section{Introduction}

Medan is the center of government, industry, commerce, and even business center in North Sumatera. In the data from Central Bureau of Statistics (BPS), North Sumatera Province, North Sumatera has a growth rate of $2.33 \%$ per year and economic growth of $14.7 \%$ per year. By all means, this data effect on trade sector, industry sector, entertainment sector, and education sector.From the data above can be obtained that Medan needs supporting facilities to organizing even such as conference, exhibition, a party even, or concert which nationally or internationally. Medan already has several Convention center, but with greatly increasing development in this city of Medan with the many activities that require convention room. Therefore, Medan is still in need of a Convention Center that can accommodate the needs of the citizen of Medan. The international convention center design is also expected to improve the quality and quantity of similar development for community place and improve the economy of Medan with regions and other countries.

\footnotetext{
*Corresponding author at: Department of Architecture, Faculty of Engineering, Universitas Sumatera Utara,

Jalan Perpustakaan Gedung J07, Medan 20155, Indonesia

E-mail address: andaluciazurdani@gmail.com
} 


\section{Literature Review}

A convention is a meeting of a group of people for a common purpose or to exchange thoughts, opinions, and information about a matter of mutual concern. The convention is widely used to describe a traditional gathering or meeting of all group members [1]. Center is derived from English which means center or center. The Convention Center is a building that serves as a central venue for meetings and performances. Not only for meeting people but also as a place of art performances in the form of music, theater, and dance.

Contemporary architecture is a style of architecture flow in its characteristic time-freedom of expression, the desire to show something different and to be a new flow or merging of several architectural streams [3]. Afterward, contemporary architecture is an architectural style that aims to demonstrate a certain quality especially in regarding technological progress and also in expressing an architectural style, trying to create a real state apart from a community that is not by [2]. Thereafter, contemporary are forms of architectural flows that cannot be grouped in a stream or otherwise various architectures are included in it [4]. Thus, it can be concluded that contemporary architecture is an architecture created and known today not in the past orthe future. Based on form, contemporary architecture is an architecture that takes the form of a monumental building which in its time is known as contemporary architecture.

\section{Methodology}

Reference design site selection is constituted by spacial plans (RTRW) West District Area. According to RTRW design site is be destined for several functions such as economics service center, transportation service center, and socio-cultural activities center. In making this analysis, several approaches related to the purpose of the role, such as field survey, to collect site design data in the form of photographs of the site state, participant observation, and then make literature studies to design the buildings to be designed.

\section{Result and Discussion}

According to the Medan special plans, site location Based on the special plans of Medan, the location of the site located in the District of West Medan is a sub-district located in the area of economic development, social culture, and transportation of the western region. The design location is at Jl. H. Adam Malik, West Medan District, North Sumatra, Indonesia (Figure 1). This location is chosen because by the West Medan District, which is destined for the commercial building to support the economy. The design themed is Contemporary Architecture. 


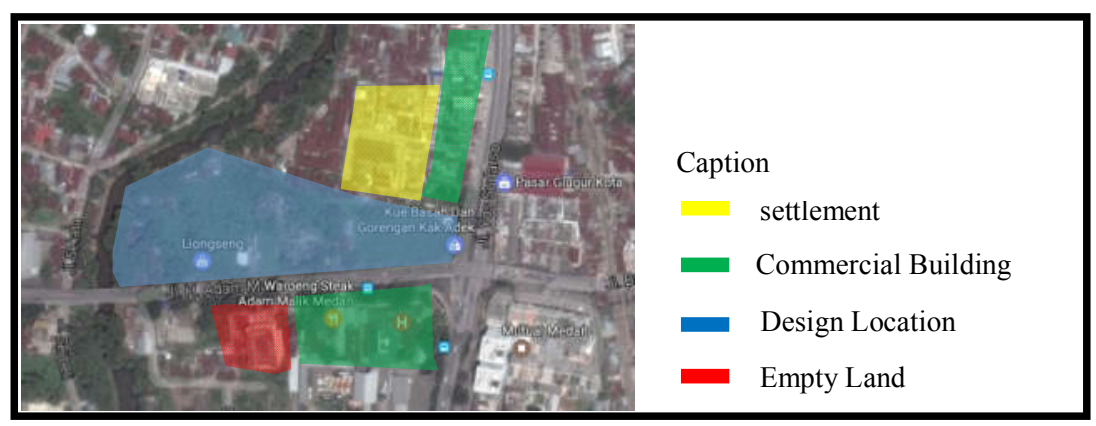

Figure 1. North Sumatera Convention Location

North Sumatra Convention Center, is a building that works for exhibition, concert performances, and formal events that require mass in massive amounts. Medan as one of the largest cities in Indonesia is in need of functioning buildings and capacity like this because it can help the development of Medan as a tourist-friendly area and international events. It can be seen that all the cities that have always been the destinations of international events are cities in Java and Bali, so it is necessary to see the development of such buildings, as an attraction to increase tourism in Medan. Given later this building is expected to welcome many guests and foreign tourists, this building is expected to be a good representative, so the theme of Contemporary Architecture becomes an option (Figure 2).

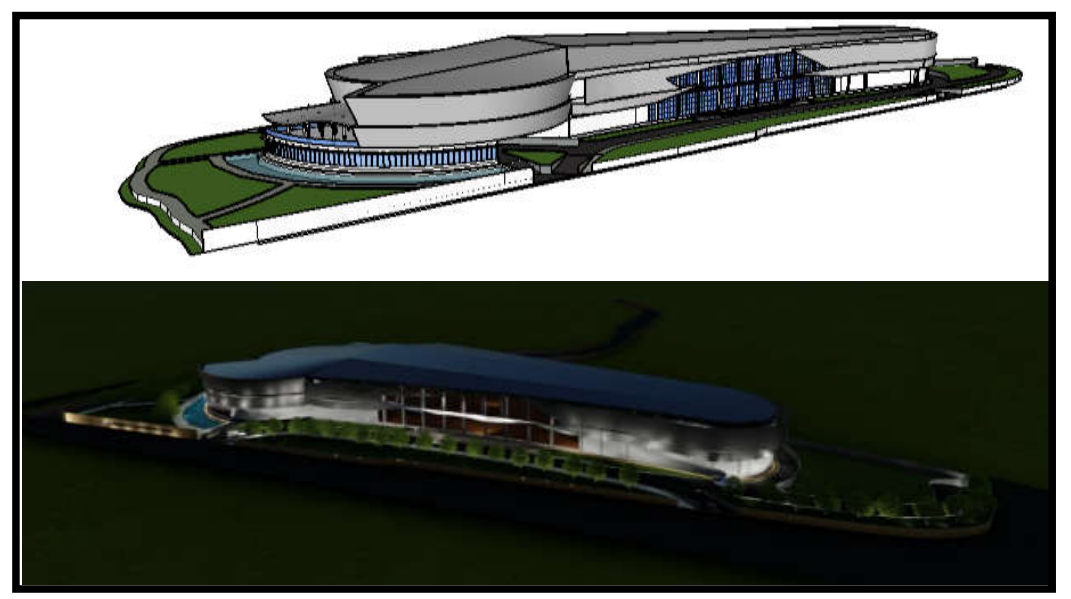

Figure 2. North Sumatera Convention Center

Soft elements in the design of North Sumatra Convention Center site is vegetation in the form of trees and other plants (Figure 3). Vegetation in the design site other than as greening also as a barrier such as trees planted along the circulation path of the design site as a barrier between the path of the vehicle with pedestrians and green spaces. With the trees placed on the edge of the lane of the vehicle is expected toprovide information to visitors to the limits of pedestrian territory and lane vehicles. Then, also as a shade that can protect visitors from the sun or rain. In addition to soft elements, there are also hard elements that are designed to the space outside this building. Among other things is the pedestrian pavement contained in this site in the form of 
brown paving blocks that can bring a natural impression of the green site and add aesthetic value on the landscape convention center. Then, there are also street lights placed on two sides of the pedestrian for night lighting which can also be aesthetic of the lighting effects caused (Figure 3).

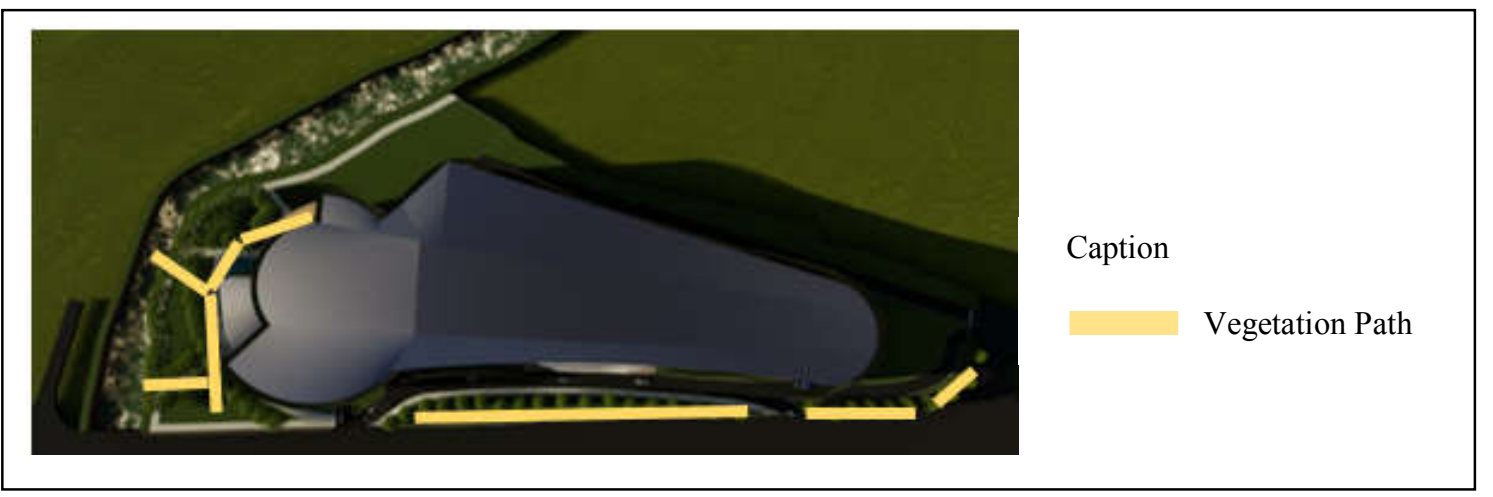

Figure 3. Soft and Hard Elements in the Design of North Sumatera Convention Center

North Sumatra Convention Center is designed to have a total of five floors. The bottom floor is a basement that serves as a parking lot. Then, one floor above it is the hall and above it is a ground plan that serves as the main convention, office and other needs (Figure 4). The concept of building mass North Sumatra Convention Center was formed due to the form of land to produce the mass of buildings in the form of a trapezoid. The concept of building using glass materials and aluminum panels, the impression to be displayed is a modern and latest building (Figure 5). Building Convention Center is a building that serves as a gathering place for people in various types of events. Convention center requires a large room freeof columns and bulkhead. Therefore the convention center building using wide-span structure. The wide span structure used is the space frame. Convention center is a building that does not have many rules in designing, so there are many convention centers that have a more free form. This structure is chosen because it is more flexible to form a building, especially a roof and more flexible in the construction work.Space Frame is a space frame that uses a connection system between the bars connected to a steel ball or ball joint. The space frame connection system will form a triangle with a join-join steel ball. Space frames are designed mediums such as dome, pyramid or other forms, especially for large spans and widths that require column-free space. 


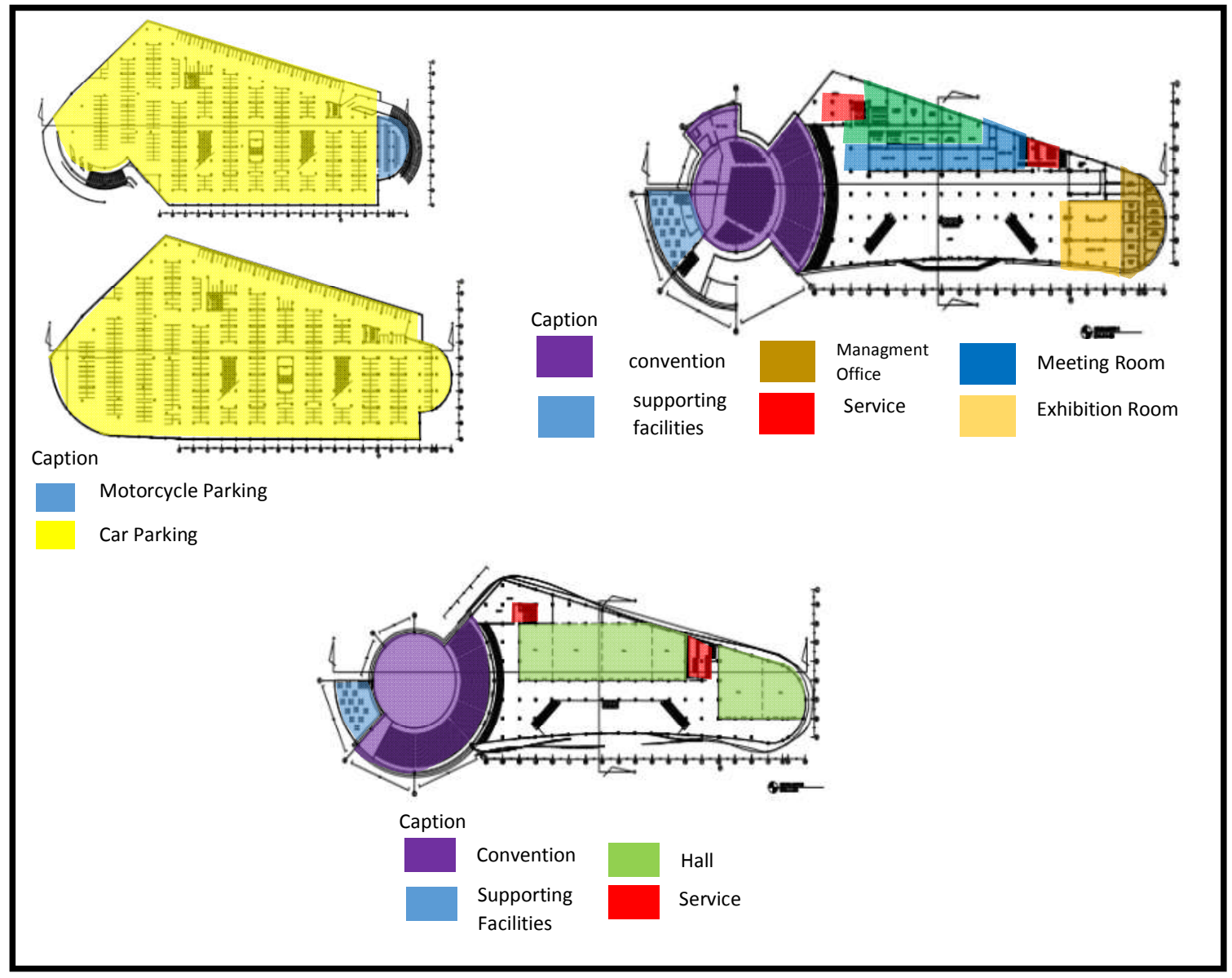

Figure 4. North Sumatera Convention Center Zoning

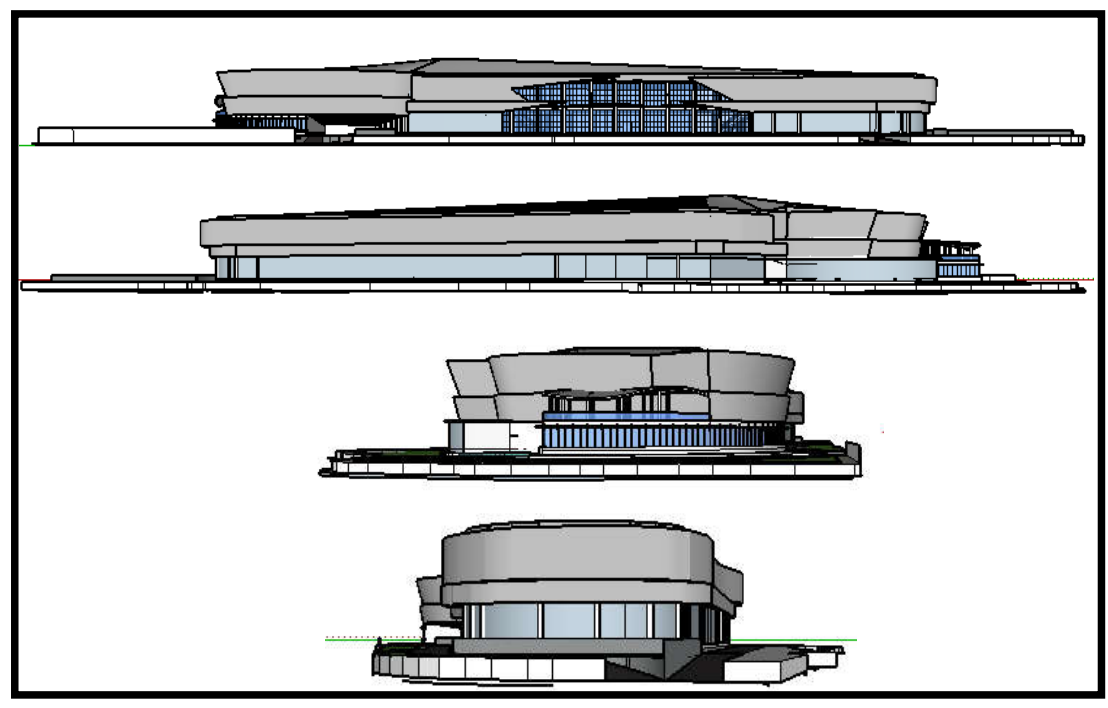

Figure 5. Mass and Apperance

\section{Conclusion}

The city of Medan is one of the largest cities in Indonesia, which has increased the needs of its people, not only in the form of primary support facilities but also complementary support 
facilities, such as hall / multipurpose building. The development of this need is strongly based on the increasing diversity of Medan immigrants, plus activities that are also increasingly diverse in this city. Various activities are held, in the form of meetings, conferences, to performing arts. In other large cities, such activities can increase significant regional revenue, while also being able to increase the number of visits from out-of-town immigrants, both domestic and foreign. The design of the North Sumatra Convention Center is expected to support the major activities mentioned above. Medan Convention Center was built at Jalan $\mathrm{H}$. Adam Malik. This location was chosen because in accordance with the District of West Medan, which is destined for commercial building supporting the economy. The design is themed Contemporary Architecture; this theme is the result of the author's thought to make this building also become Landmark of Medan. North Sumatra Convention Center has facilities such as Hall, Exhibition Hall, Meeting Rooms, and Concert Hall. With the facilities provided, is expected to attract visitors or investors to hold an international class event in the city of Medan. Where this can help the city of Medan better still in the eyes of the International as well as the National

\section{Acknowledgment}

This research is part of the requirement to obtain a bachelor's degree in Architecture Departement, Faculty of Engineering, Universitas Sumatera Utara, Indonesia.

\section{REFERENCES}

[1] F. R. Lawson. Conference, convention, and exhibition facilities: a handbook of planning, design, and management. Butterworth-Heinemann. 1981.

[2] J. Tietz, W. Hoffman, W \& P. Meuser. The story of architecture of the 20th century. Konemann. 1999.

[3] L. Hilberseimer. Contemporary architecture: Its roots and trends. Chicago, III.: P. Theobald. 1964.

[4] S. Yulianto. Arsitektur Modern Akhir Abad XIX dan Abad XX. 1997. 